\title{
Updated International Private Law of Russia
}

\author{
By Vladimir Orlov
}

The article presents the Russian international private law subjected to changes in 2013. It examines the general provisions and special rules concerning personal status, form of transaction, representation statute, property statute, and statute of limitations, as well as the obligation statute rules applicable to contracts. Due to the effectiveness of these new developments, where judicial practice and international standards have been successfully integrated into the renewed legal rules, the consistency and coherence of the part of the Civil Code containing international private law rules have been secured.

Keywords: applicable law, choice of law, statute, form of transaction, ordre public

\section{Introduction}

Civil law relations, including business law relations, of an international character are regulated in Russia by the norms of international private law, contained in the third part of the Civil Code. ${ }^{1}$ They have become subject to changes under the Law 260-FZ of September 30, 2013. The purpose of the amendments was to ensure that the legislation corresponded to the established judicial praxis. In addition, international, and in particular EU international private law legislation has been followed. ${ }^{2}$ The most radical changes to Russian law have concerned the form statute rules, where the abolishment of the formal requirements in respect of foreign trade transactions enacted by the Law 100FZ of May 7, 2013, has been enforced ${ }^{3}$. Moreover, the renewed international private law provisions have enlarged the choice of law possibilities with respect to not only the contract statute, including participation agreements, but also the tort liability statute. Furthermore, the default provisions of the law

\footnotetext{
* Dr. of Legal Sciences; Professor, Herzen State Pedagogical University of Russia, Saint Petersburg, Russia and Adjunct Professor, University of Helsinki, Helsinki, Finland.

${ }^{1}$ Enacted by the law 146-FZ of November 26, 2001. The provisions of the international private law are commented in Abova, Boguslavsky \& Svetlanov (2010) at 125-98, Stepanov (2016) at 1122-68 and Abova, Boguslavsky, Kabalkin \& Lisicin-Svetlanov (2007) at 948-1016.

2 Including Rome I (Regulation (EC) no 593/2008 on the Law Applicable to Contractual Obligations and Rome II (Regulation (EC) no 864/2007 on the Law Applicable to Noncontractual Obligations. For more on the subject see e.g. Doronina (2010) at 114-26. The amendments are presented on the website of KonsultantPlus: http://www.consultant.ru/docu ment/cons_doc_LAW_152471/ (last accessed May 9, 2016). In English, they are commented on http://www.agp.ru/upload/iblock/519/519354c3677bd1541d9f1eeac42d1966.pdf and http:// www.debevoise.com/files/Publication/a55658bd-c192-41c0-aa03-e6abedddc53d/Presentation/ PublicationAttachment/879cd75a-89bf-459c-8119-ea718c7f9563/Entry\%20into\%20Law\%20o f\%20Bundle\%20of\%20Amendments\%20to\%20Russian\%20Civil\%20Code\%20-\%20Section\% 20on\%20Private\%20.pdf (last accessed Sept. 15, 2014).

${ }^{3}$ Russian law provided the requirement of written form for such a transaction (contract) under threat of nullity.
} 
applicable to a contract, in the absence of the choice of law clause, have been clarified. The paper also considers rules on the representation statute and the fraudulent contract negotiations (culpa in contrahendo), as well as on tort liability, subrogation and set-off. One may reasonably argue that the Law 260FZ of 2013 has brought more clarity and flexibility to the Russian private law. The purpose of this article is to present the Russian international private law provisions as now updated.

\section{Basics of the Russian International Private Law}

The main part of the provisions of the Russian international private law contains the conflict of laws rules. ${ }^{4}$ The purport of these rules is not to regulate and secure societal relations directly but to determine the national law of the country to be applicable to a concrete case. ${ }^{5}$ In addition to domestic law norms, foreign law or rules of an international treaty may have to be applied. The main purpose of the international private law provisions is to determine the cases in which the private law of the state where the action is pending or lex fori, ${ }^{6}$ or the private law of a foreign state ${ }^{7}$ is to be applied. These provisions are contained in the third part of the Civil Code.

The international private law rules included in the third part of the Civil Code are basic in nature, and norms regulating civil law relations of an international character may also be contained into other legal acts. Such norms are included in the normative acts concerning leasing and pledge, among others. Furthermore, family and labour law relations of an international nature are regulated separately in Russian law. In this respect, it is important to note that the international private law norms of the third part of the Civil Code do not contain international civil process law rules, which are not considered in Russian doctrine to belong to international private law. ${ }^{8}$ In the Russian legal system they are included in the civil process law norms. ${ }^{9}$

The international private law norms in the third part of the Civil Code contain general provisions ${ }^{10}$ and choice of law rules concerning legal status of

\footnotetext{
${ }^{4}$ The Russian doctrine has not identified the international private law rules to the the conflict of laws rules. Therefore, the Russian international private law includes in addition to the choice of law rules also the material norms. See Abova, Boguslavsky \& Svetlanov (2010) at 125-26. In the larger sense, the concept of international private law in Russia also occasionally covers the rules of international civil procedure. See e.g., Neshatayeva (2004) at 19.

${ }^{5}$ See Stepanov (2016) at 1122.

${ }^{6}$ The law of the jurisdiction where the action is pending.

${ }^{7}$ The governing law is to be determined by applying choice of law or conflict of laws norms.

${ }^{8}$ In the Russian doctrine, the Russian international private law is regarded as a separate field of law and characterised as a system comprised of principles, internal and international conflict of laws norms and uniform material international private law norms. They regulate private law relations complicated by foreign element through solving collisions of private laws of different States. See Dmitrieva (2010) at 37-38.

${ }^{9}$ See Abova, Boguslavsky, Kabalkin \& Lisicin-Svetlanov (2007) at 948-51.

${ }^{10}$ Russian Civil Code, Part III, Ch. 66, arts. 1186-94.
} 
physical and juristic persons, ${ }^{11}$ as well as property law and personal no property law relations. ${ }^{12}$ The choice of law rules of the Civil Code concern the legal status of physical and juristic persons as well as other subjects of international private law. In accordance with this legal order, the private law questions closely related to a person are determined. In turn, the choice of law provisions of the Civil Code concerning property law and personal no property law relations contain the rules on the law applicable to property rights as well as to the statute of limitations and form of transaction. In addition, they include the obligation statute rules or the rules determining the law applicable not only to a contract (contract statute) but also to obligations arising from unilateral transactions. These include assignment of a claim and payment of interest as well as obligations arising from causing harm or tort liability and from unjust enrichment or unjustified enrichment, ${ }^{13}$ as well as from unfair competition and restrictions of competition. ${ }^{14}$ The choice of law rules of the obligation statute contain also the provisions on the law applicable to liability for defective products, works and services (product liability ${ }^{15}$ ) as well as the law applicable for establishing permissibility of claims for compensation of damages against an insurer. ${ }^{16}$ The applicable law provisions of the Civil Code concerning property law and personal non-property law relations have been amended under the Law of 2013 by the other choice of law rules. These govern the representation relationships,${ }^{17}$ the transfer of the creditor's rights to another person grounded on the law ${ }^{18}$ and the termination of an obligation by setoff ${ }^{19}$ as well as the fraudulent contract negotiations (culpa in contrahendo). ${ }^{20}$ The third part of the Civil Code ends with the rules determining the law applicable to relations arising from succession. This article handles in detail the general provisions and special rules concerning personal statute, form of transaction, representation statute, property statute, and statute of limitations, as well as the obligation statute rules applicable to contracts, including immovable property contract, and foundation and participation agreement.

\section{General Provisions}

The general international private law provisions of the third part of the Civil Code, ${ }^{21}$ define sources of international private law, the scope of application of the international private law norms of the Civil Code, and their

\footnotetext{
${ }^{11}$ Id. at Part III, Ch. 67, arts. 1195-1204.

${ }^{12}$ Id. at Part III, Ch. 68, arts. 1205-1224.

${ }^{13} I d$. at arts 1219-20, 23 and 23.

${ }^{14} \mathrm{Id}$. at art. 1222.

${ }^{15}$ Id. at art.1221.

${ }^{16} \mathrm{Id}$. at art. 1220.

${ }^{17} I d$. at art. 1217.

${ }^{18}$ Id. at art. Article 1216.

${ }^{19} \mathrm{Id}$. at art. Article 1217.

${ }^{20}$ Id. at art. Article 1222.

${ }^{21}$ Russian Civil Code, Ch. 66.
} 
relation to the international material law norms. Furthermore, it contains the general choice of law rule and the rules on qualification or characterization of legal concepts, as well as the provisions on application of foreign (state) law and on public order (ordre public) that impose the limits for the application of foreign law.

\section{Legal Sources}

In accordance with Article 1186 of the Civil Code, the Russian international private law rules, under which the law applicable to civil law relations of an international character is determined, are comprised of the norms of international treaties of the Russian Federation and the Civil Code Cof $^{22}$ as well as of the federal laws adopted in accordance with it. ${ }^{23}$ The position of the norms of international law is enforced in Russian law at the constitutional level, ${ }^{24}$ and if an international treaty of the Russian Federation establishes rules that differ from those stipulated by law, then the rules of the international treaty are to be applied, and this rule applies also to the conflicting civil law norms. According to the Civil Code, ${ }^{25}$ international treaties of the Russian Federation are to be applied to the relations directly regulated by the civil legislation, except in cases when it follows from an international treaty that the adoption of an internal legal act is required for its application. Moreover, Article 1186.3 of the Civil Code determining the law applicable to civil law relations contains the rule prioritizing international law norms, in accordance with which the international material law norms contained in an international treaty of the Russian Federation supersede the application of conflict of laws or choice of law norms to the question at issue. ${ }^{26}$

The law applicable to civil law relations is also to be determined, according to the Civil Code, ${ }^{27}$ on the basis of customs recognised in the Russian Federation. With respect to contract law relations, the international private law provisions of the Civil Code include additionally the rule that governs when generally accepted in international trade commercial terms, for instance Incoterms, ${ }^{28}$ are used in the contract. In such cases, unless otherwise provided by the contract, the parties are deemed to have agreed on the application of customs embodied in those terms to their relations. ${ }^{29}$

\footnotetext{
${ }^{22} I d$. at arts. $1186-224$

${ }^{23} I d$. at art. 3.2.

${ }^{24}$ Russian Constitution, art. 15.4.

${ }^{25}$ Russian Civil Code, art. 7.2.

${ }^{26} I d$. at art. 1186.3 .

${ }^{27} \mathrm{Id}$. at art. 1186.1 .

${ }^{28}$ For information concerning Incoterms, standard international trade contract terms compiled and maintained by the International Chamber of Commerce, see http://www.iccwbo.org/pro ducts-and-services/trade-facilitation/incoterms-2010/the-incoterms-rules/.

${ }^{29}$ Russian Civil Code, art. 1211.11.
} 


\section{Scope of Application}

The international private law rules of the Civil Code are applied to civil law relations of an international character. These are, according to Article 1186.1 of the Civil Code, relations with the participation of foreign physical and juristic persons or civil law relations complicated by another foreign element, including cases where the object of civil law rights is located abroad.

Although the application of international private law rules of the Civil Code is general, it is, however, allowed to deviate from them in disputes covered by an international commercial arbitration procedure. The Civil Code directly provides that the peculiarities of determining the applicable law in an international commercial arbitration shall be established by the law on international commercial arbitration. ${ }^{30}$ Such provisions are contained in the Russian law on international commercial arbitration procedure (1993). In accordance with its Article 28.2, in the absence of the choice of law clause, arbitrators of the commercial arbitration court shall decide on the choice of substantive law applicable to the substance of the dispute in accordance with the conflict of laws rules that they may find applicable to the case.

\section{General Choice of Law Rule}

The international private law rules of the Civil Code determine in great detail the cases when the civil law issue of international character is governed by Russian law or foreign law. With respect to cases in which the determination of applicable law under the Russian international private law norms is impossible, the Civil Code provides a safety valve rule for general application. ${ }^{31}$ According to that rule, in such a case the law of the country with which the civil law relation is most closely related, or the law of closest connection, or the law of the most significant relationship is to be applied. ${ }^{32}$

\section{Qualification}

Qualification or characterization comprehends usually the legal definition of facts and circumstances relevant for the issue subject to consideration, and the general provisions in that regard are contained in the Civil Code. ${ }^{33}$ They comprise both main and subsidiary rules. According to the main rule, in the determination of the applicable law, the interpretation of legal concepts used in qualification is to be governed by the Russian law, unless otherwise provided by the law ${ }^{34}$. In turn, the subsidiary rule ${ }^{35}$ is purported for the cases when the

\footnotetext{
${ }^{30} I d$. at art. 1186.1 .

${ }^{31} I d$. at art. 1186.2.

32 This means the choice of the law of the state that is the least prejudiced to the public interests (values) related to the legal relationship. Primarily, it is the law of the jurisdiction (state) where the action is pending or lex fori, See, e.g., Stepanov (2016) at 1124.

${ }^{33}$ Russian Civil Code, art. 1187.

${ }^{34} I d$. at art. 1187.1.

${ }^{35} I d$. at art. 1187.2.
} 
legal concepts requiring qualification are not known to Russian law or are known in another verbal designation or with the other content and cannot be determined by interpretation under Russian law. In such a case, the foreign law may be applied. ${ }^{36}$

\section{Application of Foreign Law}

The international private law rules of the Civil Code contain mainly twosided conflict of laws rules consisting of the principle or rule on the basis of which the applicable law shall be chosen; the question is of the choice between the Russian legal order and the one of a foreign state. Conflict of laws rules are, however, merely choice of law rules, and though they are the legal ground for the application of foreign law, ${ }^{37}$ they do not contain the answer to a material question. They only indicate the national legal order on the basis of which the legal question is resolvable. Moreover, in the event the applicable law under the choice of law rule is the law of a foreign state, then the question arises as to how the content of a foreign law is to be ascertained.

The international private law norms of the Civil Code include rules that help in the determination of the content of the foreign law. The application of foreign law would include such questions as the application of the law of a country with a multiplicity of legal systems, reverse reference or renvoi, reciprocity, retorsion and public order or ordre public, the rules on which are provided in the international private law norms of the Civil Code.

\section{a) Establishment of the content of foreign law}

Article 1191.1 of the Civil Code regulating the establishment of the content of foreign law contains the basic rule, according to which, in the application of foreign law, a court establishes the content of its norms in compliance with official interpretation, application practices and doctrine in the respective foreign state. Thus, a Russian court must ex officio or on its initiative (officially) take into consideration the norm of foreign law and apply it. The general requirement is that the foreign law must be applied with the same content as it is applied in the respective foreign state, and it must be applied as legal norms or legally peremptory provisions. ${ }^{38}$ Under the obligation

\footnotetext{
${ }^{36}$ In fact, qualification takes place in two stages. For the first, the content of the legal concept ought to be clarified according to the lex fori in order to find the applicable choice of law rule (preliminary qualification). In the second, following, stage, the (proper) qualification is determined according to the applicable law (lex causae). See, e.g., Stepanov (2016) at 1125.

${ }^{37}$ The application of foreign law is understood in the Russian legal doctrine as that a) it may be applied by courts and other bodies of administration of justice, and b) if it is referred to, then its application is obligatory for authorities, and c) it comprehends the legal norm system or legal substance. See Dmitrieva (2010) at 146.

${ }_{38}$ According to the Russian international private law doctrine, in the application of foreign law, its content must be clarified not only on the bases of the legislative texts of the respective State but also by resorting to the official interpretation, legal consciousness, legal doctrine and legal practice in the country. See Dmitrieva (2010) at 147.
} 
of a court is also that the content of the foreign law is clarified. ${ }^{39}$ In order to establish the content of norms of foreign law the court may apply for assistance and clarification, according to the Civil Code ${ }^{40}$ to the Ministry of Justice of the Russian Federation and other competent bodies or organizations, including research institutes, in the Russian Federation and abroad. The court may also use the services of experts.

In this process of clarification, parties to a case may present the documents confirming the content of foreign law norms to which they refer to in order to justify their claims. ${ }^{41}$ The parties may also assist the court in other ways in clarifying the content of such norms. Thus, the parties have only the right to aid in clarification of legal norms applicable to their dispute (or other legal issue), but the legal consideration in the case belongs to the court. In the event the claims of the parties are related to enterprise activities, the obligation of presenting information ${ }^{42}$ about the content of foreign law may be placed by the court upon the parties ${ }^{43}$.

The provisions of the Civil Code on the establishment of the content of foreign law also contain the rule regulating the situation when the content of a foreign law norm cannot be clarified within a reasonable time despite the aforementioned measures. ${ }^{44}$ In such a case, Russian law is to be applied, with the result that the establishment of the content of foreign law would be governed by the lex fori.

\section{b) Internal multiplicity of legal systems}

In the application of the law of a foreign state, a problem may arise if the state in question has multiple legal orders. Ordinarily, these are states divided into administrative territorial units, such as federative states. In such a case, referred to as an inter-local collision occasion, the Civil Code provides special rules. $^{45}$ The provision on multiplicity of legal systems also contains a safety valve rule. In the event the applicable law is the law of a country where several systems of law are in effect, the legal system of law determined in compliance with the law of that country is to be applied. However, if under the law of that country it is impossible to determine which of the legal systems is applicable, the legal system with which the relation is most closely connected is to be applied. The rules on inter-local collisions are also applicable to cases of

\footnotetext{
${ }^{39}$ Thus, the application of foreign law is equated with the application of the national law.

${ }^{40}$ Russian Civil Code, art. 1191.2.

${ }^{41} I d$.

42 Thus, according to the amended provision, the party may not be charged with the duty to prove the content of foreign law. It reflects the established judicial practice in Russia. For more on the subject see Информационное письмо Президиума Высшего Арбитражного Суда Российской Федерации N 158 [Information Letter of the Presidium of the Supreme Arbitrazh Court of Russian Federation no 158]. http://arbitr.ru/as/pract/vas_info_letter/89295.html (last accessed May 9, 2016).

${ }^{43}$ Russian Civil Code, art. 1191.2.

${ }^{44} I d$. at art. 1191.3.

${ }^{45} \mathrm{Id}$. at art. 1188.
} 
interpersonal collisions, when different groups of person are governed by different legal norms. ${ }^{46}$

c) Renvoi

The main purpose of the conflict of laws norms or choice of law rules is to indicate the law applicable to an individual case or lex causae. Sometimes, however, the reference to the law of state $A$ by the courts of state $B$ may lead to a situation where the choice of law rules of state $A$ may refer to the application of the norms of state $B$. The result, which is called renvoi or reverse reference, would require that the issue "returns" for resolution under the law of the state applying choice of law rules. It is also possible that the choice of law rules of state $A$ may refer forward to the law of some third state $C$, in which case a situation called forward reference may occur.

In respect of these situations, the Civil Code rule on reverse reference ${ }^{47}$ is that a reference to a foreign law is regarded as a reference to the material law of the respective state but not to its conflict of laws norms ${ }^{48}$ or choice of law rules. However, there is an exception from the general rule ${ }^{49}$ as to the determination of the personal status of a physical person. In such a case, reverse reference to foreign law is applicable where the reference is to Russian law.

\section{d) Reciprocity}

Among the basic rules of Russian international private law is the requirement that the courts and other judicial authorities are under a duty to apply the foreign law indicated by choice of law rules without any demand for reciprocity. According to Article 1189.1 of the Civil Code, foreign law is applicable in the Russian Federation irrespective of the applicability of the Russian law to similar relations in the respective foreign state. However, as an exception, it is possible that the law imposes a requirement of reciprocity for the application of a foreign law. In this case or if the application of a foreign law depends upon reciprocity, this is to be presumed, unless proved otherwise. Thus, according to the Civil Code, the principle of reciprocity is in such a case in effect until proved to the contrary. ${ }^{50}$

\footnotetext{
${ }^{46}$ The same way are also handled so-called intertemporal collisions arising due to the existence of the legal norms, enacted at different times, which regulate the same legal relations. In practice, it means that the implementing provisions of the applicable law must be taken into consideration. For more on the subject see Dmitrieva (2010) at 153-54.

${ }^{47}$ Russian Civil Code, art. 1190.

${ }^{48} I d$. at art. 1190.1 .

${ }^{49} I d$. at art. 1190.2 .

${ }^{50}$ Dmitrieva (2010) at 155 . However, this presumption rule is not extended to the enforcement of foreign court judgments in Russia, where the presence of reciprocity is to be found in the court proceedings. This viewpoint is also enforced in the Russian judicial practice. See Yarkov (2007) p. 131 and Stepanov (2016) at 1127.
} 


\section{e) Retorsions}

International private law norms of the Civil Code also contain rules on retorsions, which are counter-measures provided by international law, by means of which the state may reply to unfriendly acts of another state. According to the Civil Code, reciprocal limitations (retorsions) may be established by the Government of the Russian Federation. ${ }^{51}$ They may involve limitations on the property and personal non-property rights of citizens and juristic persons of the states.

\section{Ordre Public and Directly Applicable Norms}

As a concept, ordre public is connected with the fact that, in general, the state imposes principled limits on the applicability of foreign law. Such terms as public order, foundations of the legal order and principle of absoluteness, as well as public policy are commonly used as equivalents to ordre public. The basic purpose of the ordre public rule is that the applicable foreign law norms must not be contradictory to the foundations of the legal order of the state; this is so called negative ordre public or the principle of absoluteness. The ordre public or public order stands also for moral and justness or equity rules, basic interests of the state and its members, and today it also frequently comprehends generally recognised principles and norms of international law. ${ }^{52}$ The application of ordre public means that foreign law chosen through a conflict of laws norm is not to be applied, nor are the subjective rights arising under such a foreign law to be protected, if such an application or protection is against the public policy of the lex fori.

Often, the concept of ordre public also entails that the internal, directly imperative or peremptory material legal norms of the country are to be applied, irrespective of whether the otherwise material law norms of the legal order of another state chosen through a conflict of laws norm are applicable. This application of the concept is an example of so-called positive ordre public. In general, directly applicable norms comprehend domestic legal norms. On the other hand, they stand also for foreign law norms that are to be applied irrespective of whether they are contained into the legal order indicated by the choice of law rule or not. In such cases the question is of the application of foreign private law norms, since the ordre public rules belong to the private law provisions. But in considering the question of international character, a court must also consider the public law norms of foreign law. However, the court may only "take into consideration" such public law norms, since it is

\footnotetext{
${ }^{51}$ Russian Civil Code, art. 1194.

52 The Russian public order may be regarded as consisting of 1) the basic principles, in the first place, of the Constitution law, but also of the private law, 2) generally recognised moral principles on which the Russian legal order is based, 3) legal interests of Russian citizens and juristic persons as well as the legal interests of the Russian society and State, the protection of which is the main aim of the legal system of the country, and 4) generally recognised principles and norms of the international law, which form a part of the Russian legal system, including the international human rights standards. See Dmitrieva (2010) at 159.
} 
allowed to apply only foreign private law norms. It is therefore impossible in principle, through the application of choice of law norms, to ignore the legal effect of public law norms. ${ }^{53}$

The international private law norms of the Civil Code contain both negative and positive ordre public rules. The negative ordre public rule or principle of absoluteness is contained in the provision where the reservation of public order is prescribed. ${ }^{54}$ Thus, in exceptional cases a norm of applicable foreign law chosen through the international private law rules of the Civil Code shall not be applied. However, non-application of an otherwise applicable foreign law norm is allowed only if not only the content of the applicable norm but also the consequences of its application would obviously contradict the foundations of the legal order or public order of the Russian Federation, taking into account the nature of relations involving a foreign element. Thus, the application of the public order reservation requires that the disregarding of a foreign law norm is justified in casu, and as justification we have merely the observation that application of the foreign law norm would lead to a result that is against the foundations of the Russian legal order. However, the public order norm of the Civil Code directly provides that a refusal to apply a norm of foreign law may not be based merely on a difference in the legal, political or economic systems between the respective country and the Russian Federation. In the event a foreign law norm is disregarded due to the application of the ordre public rule, the relevant norm of Russian law (or lex fori) is to be applied where necessary. ${ }^{55}$ On the other hand, a legal norm of a foreign state may be applied, and is to be determined under the law of the country with which the civil law relation is most closely related, taking into account that the Civil Code safety valve rule for subsidiary application of the law of the state of closest connection to the relation. ${ }^{56}$

The positive ordre public rules are contained into Article 1192 of the Civil Code regulating the application of directly applicable imperative norms or overriding mandatory provisions. The international private law rules of the Civil Code are not to be applicable in the event the imperative norms of Russian Federation legislation govern the respective relations directly, due to an indication contained in them or in connection with their special significance, irrespective of the otherwise applicable law. ${ }^{57}$ The question is of directly applicable or absolutely imperative or peremptory (mandatory) material law norms which represent the public law element in the civil law regulation ${ }^{58}$. Among the legal norms which are to be directly applied because of their special significance, the Civil Code $^{59}$ indicates, in particular, the norms purposed for securing the rights and interests of participants in civil law relations.

\footnotetext{
${ }^{53}$ See Dmitrieva (2010) at 165-66.

${ }^{54}$ Russian Civil Code, art. 1193.

${ }^{55} \mathrm{Id}$. at art. 1193.

${ }^{56} \mathrm{Id}$. at art. 1186.2.

${ }^{57} \mathrm{Id}$. at art. 1192.1.

${ }^{58}$ Stepanov (2016) at 1130.

${ }^{59}$ Russian Civil Code, 1192.1.
} 
The provisions of the Civil Code on the application of peremptory norms make it possible for the public order of a foreign state also to be protected in Russia. According to Article 1192.2 of the Civil Code, in the application of a foreign state law determined through the choice of law rules a court may take into consideration the directly applicable norms of the country with which the civil law relation is most closely related. The precondition for taking into consideration foreign state imperative norms is that under the law of the respective country such norms must regulate the respective relations without regard to the applicable law or will be applied instantly. Thus, a Russian court may take into account directly applicable imperative or peremptory norms of the legal order of the country which has the closest connection to the legal question at issue. The question of whether or not the legal norm is of absolutely imperative or peremptory character covered by ordre public is to be solved in accordance with the conceptions of the respective legal order. However, the rules of the Civil Code on the application of these imperative norms impose an additional important requirement: the court must consider the purpose and nature of such norms and also the consequences of their application or nonapplication. ${ }^{60}$ This can mean that the Russian court may disregard such a foreign imperative norm on the ground that the result of its application would be contradictory to the Russian ordre public, in which case the norms of Russian law (lex fori) would be applicable.

\section{Choice of Law Rules}

\section{Personal Statute ${ }^{61}$}

The choice of law rules concerning the legal status of juristic persons, according to which the private law issues closely connected to a juristic person or personal statute (lex personae) are to be determined, is contained in Article 1202 of the Civil Code regulating the personal law of a juristic person. It contains, besides the choice of law rule, the list of issues which belong, in accordance with the Russian international private law rules, to the personal statute of a juristic person and which are to be determined under the personal law $^{62}$. They include:

- the status of the organization as a juristic person;

- the legal form of a juristic person;

- the requirements for the name of a juristic person;

- issues concerning the formation, reorganization, and liquidation of a juristic person, including legal succession;

- the content of the legal capacity of the juristic person;

\footnotetext{
${ }^{60}$ Russian Civil Code, 1192.2.

${ }^{61}$ Personal statute of physical persons is out of scope of this presentation.

${ }^{62}$ Russian Civil Code, art. 1202.2.
} 
- the procedure for the acquisition of civil law rights and assumption of civil law duties by the juristic person;

- internal relations, including relations of the juristic person with its participants;

- the capacity of the juristic person to respond to its obligations; as well as

- issues concerning the liability of the founders (participants) of the juristic person for its obligations ${ }^{63}$.

According to the choice of law rules concerning the legal status of a juristic person ${ }^{64}$, the personal law of a juristic person is the law of the country where the juristic person has been founded ${ }^{65}$. The foundation of a juristic person generally requires registration, wherefore the law of the state of registration is commonly regarded as a personal statute of a juristic person. Under the law of the state of registration the legal (act) capacity of a juristic person is determined and it arises at the moment of registration. The content of the rights or legal status of a juristic person is determined in accordance with its original foundation documents presented at the registration. The legal status of a juristic person may be subject to the provisions of an international treaty, which may stand for granting certain regime and reciprocal recognition. It is also possible that the nationality or legal status of a juristic person is determined by an international treaty to be the state of its site.

The provisions of the Civil Code on the personal law of a juristic person also include the rule purported to protect third persons ${ }^{66}$. According to this rule, a foreign legal entity may not refer to a limitation of the powers of its body or representative to enter into a transaction which is not known in the law of the country where the body or the representative has entered into the transaction, with the exception of cases when it is proved that the other party knew or obviously should have known of the limitation. Thus, in the event a contract is concluded in Russia, the good faith or bona fides of the Russian contracting party of a foreign legal entity is protected from the risk that the legal (act) capacity of a foreign legal entity or its representative deviates from the provisions of Russian law on it. However, when a legal entity established abroad exercises its entrepreneurial activities mainly in Russia, the liability claims for the obligations of the legal entity against its founders (participants), or other persons who are entitled to give obligatory instructions for this entity or otherwise are able to determine its actions are to be governed by Russian

\footnotetext{
63 Thus, the debtors may choose the law applicable to the question of the liability of the founders (participants) of the foreign organization, which is practicing its activities in Russia, for its obligations. See KonsultantPlus: Pravovyye novosti. http://www.consultant.ru/docume nt/cons_doc_LAW_146920/

${ }^{64}$ Russian Civil Code, art. 1202.1.

${ }^{65}$ Which is regarded as its nationality.

${ }^{66}$ Russian Civil Code, 1202.3.
} 
law or-at the choice of a creditor-by the personal law of such a legal entity $^{67}$.

The international private law norms of the Civil Code contain the rules that concern subjects of international private law other than physical persons and juristic persons. They include the state and organizations which are not juristic persons.

According to Article 1203 of the Civil Code, although a foreign organization is not a juristic person under its national law, its personal law is the law of the country where this organization was founded. In the event that Russian law is applicable to the activity of such an organization, the corresponding rules of the Civil Code regulating the activities of juristic persons are to be applied, unless it otherwise follows from the law, other legal acts, or the nature of the relation. Such an exception may be provided, for instance, by a bilateral treaty of the Russian state.

The international private law rules of the Civil Code are, according to its Article 1204, also applicable to the participation of the state in civil law relations of international character. The state participates in such relations in accordance with the general rules of international private law. This means that its legal status in international private law relations is in principle the same as that of other subjects of law. However, the law may provide otherwise, according to the Civil Code, and the most important exception is represented by the rules of state immunity.

\section{Form of Transaction ${ }^{68}$}

In Russian international private law, as in general, the law applicable to the form of a transaction (contract) or form statute is regarded as a separate question. The provisions for it are placed in their own Article in the Civil Code, which contains, besides the general provisions, special rules concerning the form of

- consumer contracts;

- agreements on establishing of the juristic person and a transaction concerning the exercise of the participation rights in a juristic person;

- transactions and changes concerning rights subjected to state registration in Russia, and

- transactions on immovable property. ${ }^{69}$

According to the general provisions ${ }^{70}$, the form of a transaction is to be governed by the law of the country, which is to be applied to the transaction

\footnotetext{
${ }^{67} I d$. at art. 1202.4.

${ }^{68}$ For more on the subject see, e.g., Dmitrieva (2010) p. 304-09 and Abova, Boguslavsky \& Svetlanov (2010) at 166-70.

${ }^{69}$ Now there are no special rules concerning the form of foreign economic transactions in Russian civil law.

${ }^{70}$ Russian Civil Code, art. 1209.1.
} 
itself $^{71}$. However, a transaction may not be recognised as invalid on the grounds of its non-compliance with the form requirements, if those of the law of the land where it is concluded have been observed (locus regit formam actus). Furthermore, a transaction concluded abroad, in which at least one of the parties is a person whose personal statute is Russian law, may not be recognised as invalid on the grounds of its non-compliance with the form requirements, if those of the Russian law have been observed. ${ }^{72}$ Thus, a transaction concluded abroad, according to Russian law, is valid in the event that the requirements of Russian law or the law of the country where it is concluded, or of the law applicable to the transaction itself, are followed. The rules of the general provisions are also to be applied to the form of a power of attorney ${ }^{73}$.

According to the special rules of the Civil Code concerning the form of agreements on establishment of the juristic person and transactions concerning the exercise of participation rights in a juristic person ${ }^{74}$, in cases where the law of the country where the juristic person is established contains special requirements concerning the form of such an agreement or transaction, their form is to be governed by the law of this country. And in the event that a transaction, or the origin, transfer or termination of rights under it, is subject to state registration in Russia, the form of such a transaction is to be governed by Russian $\mathrm{law}^{75}$. As to the form of a transaction in respect of immovable property, according to the special rule of the Civil Code concerning it $^{76}$, that is to be governed by the law of the country in which the property is located. However, according to the Civil Code, Russian law is to be applied in respect of immovable property subject to registration in Russia, including Russian aircraft, sea vessels, inland vessels and space objects. Special rules are also purported to govern consumer contracts, according to which the consumer may choose the law of the country of his residence to be applied to the formal requirements of such a contract ${ }^{77}$.

\section{Representation Statute}

The choice of law rules of the Civil Code now include, as mentioned above, the provisions on the law applicable to representation (and agency) relations or representation statute rules ${ }^{78}$. In the event that such a relation is

\footnotetext{
${ }^{71}$ This means the prohibition to choose another law than the law applicable to the form of the contract to govern the contract. See KonsultantPlus: Pravovyye novosti. http://www.consultant. ru/document/cons_doc_LAW_146920/(last accessed March 26, 2016).

72 Thus, the facultativeness of the form statute is a general rule in the Russian international private law.

${ }^{73}$ Russian Civil Code, art. 1209.1.

${ }^{74} \mathrm{Id}$. at art. 1209.2 .

${ }^{75} \mathrm{Id}$. at art. 1209.3.

${ }^{76} \mathrm{Id}$. at art. 1209.4.

${ }^{77} \mathrm{Id}$. at art. 1209.1 .

${ }^{78}$ Id. at art. $1217^{1}$.
} 
grounded on the agreement ${ }^{79}$, it is subject to the rules on the contract statute ${ }^{80}$. Moreover, representationship grounded on the law or an act of public authority is also excluded from the scope of application of the representation statute rules ${ }^{81}$.

The main purpose of the choice of law rules on representation is to regulate external representation relations, that is, those to third parties, which are mostly based on the power of attorney ${ }^{82}$. The representation statute concerns the following issues:

- the existence of the representation powers and their extent;

- the consequences of the execution of representation;

- the requirements on the content of the power of attorney;

- the term of the power of attorney;

- the termination of the power of attorney, including the consequences of it to third parties;

- the permissibility of redelegation of the power of attorney, and

- the consequences of unauthorised representation, including subsequent approval of the transaction ${ }^{83}$.

The law applicable to the external representation relations or relations between the representee or representative and the third party is, unless otherwise follows from the law, the law chosen by the representee in the power of attorney, provided that the third person and representative has been informed about it. In its absence or, if the choice of law is not effective, the relations between the representee or representative and the third party are to be governed by the law of the country in which the place of residence or main place of activities of the representative is located, and (if this is, or ought to be, unknown to the third party) the law of the country in which the representee has mainly practiced his activities in the concrete case ${ }^{84} .{ }^{85}$ If, however, the object of the representation is immovable property and this is subject to state registration, then the law where the property is registered is applicable ${ }^{86}$.

The representation statute provisions of the Civil Code contain the rules where the object of the representation is judicial proceeding ${ }^{87}$. It is to be

\footnotetext{
${ }^{79}$ According to Article $1217^{1} .7$ of the Civil Code, representation grounded on the law or act of public authority is excluded from the scope of application of the choice of law rules on representation.

${ }^{80}$ Russian Civil Code, $1217^{1} .1$.

${ }^{81} \mathrm{Id}$. at art. $1217^{1} .7$.

${ }^{82}$ In turn, the internal representation relations (between the representative and representee) are governed by the contract statute rules.

${ }^{83}$ Russian Civil Code, art. $1217^{1} .5$.

${ }^{84}$ In particular, these choice of law rules are comparable with the provisions of the Hague Convention on the law of 1978. See Asoskov (2015).

${ }^{85}$ Russian Civil Code, art. $1217^{1} .2$.

${ }^{86} \mathrm{Id}$. at art. $1217^{1} .3$.

${ }^{87}$ The representation powers are presumed, according to Article $1217^{1} .6$, to include judicial representation in Russia.
} 
governed by the lex fori or the law of the jurisdiction (country) where the action is pending ${ }^{88}$. Furthermore, according to Article $1217^{1}$ of the Civil Code, unless otherwise follows from the law or the nature of relations, it is regarded in default of any other stipulations in the power of attorney - that the scope of the representation powers of the representative covers

- the determination of the order of resolution of disputes, including agreements on it, as well as

- the choice of law applicable to the transactions concluded by the representative in the name of the representee ${ }^{89}$.

\section{Property Statute}

The rules on the property statute determine the legal order of the state the norms of which are to be applied in considering material law questions belonging to property law, and in Russian international private law they are contained in the Civil Code as the general provisions on the law applicable to property rights $^{91}$, including the scope of its application ${ }^{92}$, as well as the rules on the law applicable to the emergence and termination of property rights ${ }^{93}$ and the property rights to ships (crafts) and space objects ${ }^{94}$.

The rules on the scope of application of the law applicable to property rights ${ }^{95}$ concern the issues that form the content of the property statute. The issues on which the applicable law is determined in Russian law according to the rules on property statute include, unless otherwise provided by the Civil Code:

- the types of objects of property rights, including belonging of property to immovable or movable things;

- the alienability of objects of property rights;

- the types of property rights;

- the content of property rights;

- the emergence and termination of property rights, including transfer of ownership;

- the exercise of property rights, and

- the protection of property rights.

\footnotetext{
${ }^{88}$ Russian Civil Code, art. $1217^{1} .4$.

${ }^{89} \mathrm{Id}$. at art. $1217^{1} .6$.

90 This rule was before established in the Russian judicial practice. See the Rulings of the Presidium of the Supreme Arbitrazh Court no 18170/09 of 1 June 2010 and no 12311/10 of 12 April 2011, mentioned in Asoskov (2015).

${ }^{91}$ Russian Civil Code, art. 1205.

${ }^{92} \mathrm{Id}$. at art. $1205^{1}$.

${ }^{93} \mathrm{Id}$. at art. 1206.

${ }^{94} I d$. at art. 1207.

${ }^{95} \mathrm{Id}$. at art. $1205^{1}$.
} 
According to the general provisions concerning property rights (the property statute), the right of ownership and other rights to immovable and movable property are to be determined according to the law of the country where the property is located ${ }^{96}$. Thus, Russian international private law has adopted the lex rei sitae rule. ${ }^{97}$ Instead, the applicable law to the ownership and other property rights to aircraft, sea vessels, inland vessels and space objects that are subject to state registration, as well as the exercise and protection of those rights, is the law of the country where the said object is registered ${ }^{98}$.

According to the rules of the Civil Code on the law applicable to the emergence and termination of property rights ${ }^{99}$, this is determined by the law of the country where such property was located at the time when the legal fact for the emergence and termination of the right was present. Thus, the ownership and other property rights to the thing once acquired shall remain constant, or the ownership right to the thing legally transferred to the ownership of another person in another state shall remain effective even though the thing is transferred to the other state. However, although the ownership right to the thing acquired abroad shall remain, its content may change.

Additionally, the provisions of the Civil Code on the law applicable to the emergence and termination of property rights contain the rule ${ }^{100}$ that applies to the movable property en route, for instance goods in transitu. According to this rule, the emergence and termination of a right of ownership or other property right under transaction concluded in respect of such property is to be determined by the law of the country from which the property was sent, unless otherwise provided by the law. In respect of movable property, the parties may however also agree on the law applicable to their transaction concerning the emergence and termination of the right of ownership and other property rights without prejudice to the rights of third persons. ${ }^{101}$

The provisions of the Civil Code on the law applicable to the emergence and termination of property rights also contain the rule ${ }^{102}$ on the emergence of ownership and other property rights by virtue of acquisitive prescription. This is determined by the law of the country where the property was located at the time of expiry of the acquisitive prescription term. If this occurred on Russian territory, Russian law is applied, according to which the acquisitive prescription term is, in respect of immovable property, 15 years, and of other property, five years ${ }^{103}$. Additionally, Russian law provides that the rights to the property subject to registration are to arise from the moment of their

\footnotetext{
${ }^{96} I d$. at art. 1205.

97 The law of the location of the property is governed also for the property law qualification where the classification of property as immovable or movable, as the property statute issue, is to be determined, as stated above.

${ }^{98}$ Russian Civil Code, art. 1207.

${ }^{99} \mathrm{Id}$. at art. 1206.1.

${ }^{100}$ Id. at art. 1206.2.

${ }^{101}$ Id. at art. 1206.3.

${ }^{102} \mathrm{Id}$. at art. 1206.4.

${ }^{103}$ Id. at art. 234.1.
} 
registration ${ }^{104}$, unless otherwise established by the law ${ }^{105}$. Registration requirements in Russia concern the ownership right to immovable and in certain cases movable property.

\section{Statute of Limitations}

Limitation of action is regarded in Russian law as belonging to civil law, and it is related to the property law questions. According to the international private law rules of the Civil Code, the statute of limitations is determined by the law of the country governing the respective relation ${ }^{106}$. Thus, the law applicable to the statute of limitations depends on what kind of property is in question, where the civil law object is located and to which country's law it is subordinated. For instance, if the question regards demands based on a foreign economic transaction and related to the obligation statute, their limitation term is to be determined in accordance with the obligation statute.

\section{Contract Statute}

\section{a) General provisions}

The general provisions of the Civil Code on the contract statute contain, firstly, the rules on the scope of application of the law applicable to a contract $^{107}$ or the issues that form the content of the contract statute. The issues to which the applicable law is determined in Russian law according to the rules on contract statute include:

- interpretation of the contract;

- rights and duties of the parties to the contract;

- performance under the contract;

- consequences of nonperformance or improper performance of the contract;

- termination of the contract, and

- consequences of invalidity of the contract.

All these issues are related to the rights and duties of the parties to the contract. Therefore, questions which do not concern the rights and duties of the contracting parties are outside the scope of the contract statute and subject to other choice of law norms, unless otherwise provided by the law. Such issues include, firstly, those that are related to the personal statute of a juristic person, which are to be determined under the personal law, ${ }^{108}$ and those that form the content of the property statute, which are subject to the application of the law

${ }^{104} I d$. at art. 234.1.

${ }^{105} \mathrm{Id}$. at art. $8^{1} .2$.

${ }^{106} \mathrm{Id}$. at art. 1208 .

${ }^{107} \mathrm{Id}$. at art. 1215.

${ }^{108}$ Id. at art. 1202.2. 
of the country where the property is located ${ }^{109}$. Also, the issues related to the relation with the third party in representation are outside the scope of the contract statute and are partly subject to other choice of law norms.

The basic rule regarding the law applicable to the issues belonging to the contract statute is contained into Article 1210 of the Civil Code, concerning the choice of law clause. According to this rule, the contracting parties may, at the conclusion of the contract or thereafter, choose by agreement the law that will govern their rights and duties under the contract. This means enforcement of the principle of the free will or lex voluntatis in the Russian international private law. It comprehends, firstly, that the contracting parties may define the content of their contract at their discretion and determine the law applicable to it by the choice of law clause. ${ }^{110}$

According to the Civil Code, the choice of law clause or the agreement of the parties on the applicable law must be directly expressed or must become evident from the terms of the contract or the entirety of the circumstances of the case ${ }^{111}$. In the event that the choice of law clause is made after the conclusion of the contract, it has retroactive force and is considered valid, without prejudice to the rights of third persons, and to the validity of the transaction with regard to the requirement concerning its form, from the moment of conclusion of the contract ${ }^{12}$. In accordance with the Civil Code, the choice of law clause may concern the contract as whole as well as specific parts of it $^{113}$, and this means that Russian international private law recognises the situation in which different parts of the contract are governed by different laws (dépeçage).

The free will of the contracting parties or their freedom to determine the law applicable to their contract is restricted in the Civil Code not only by the above-presented rules protecting third persons ${ }^{114}$ but also by the rule on the application of imperative norms. According to this rule, if, at the time of the choice of the applicable law, all circumstances concerning the essence of the parties' relations were connected with only one country, the parties may not supersede the imperative norms of that country ${ }^{115} .116$

In the absence of the choice of law clause and unless otherwise provided by the Civil Code or another federal law, the law applicable to a contract is determined under the rules provided in Article 1211.1 of the Civil Code. This is the law of the country where, at the moment of conclusion of the contract, the place of residence or main place of activities of the party, whose

\footnotetext{
${ }^{109}$ Id. at art. $1205^{1}$.

${ }^{110} \mathrm{Id}$. at art. 1210.1 .

${ }^{111} \mathrm{Id}$. at art. 1210.2.

${ }^{112}$ Id. at art. 1210.3 .

${ }^{113}$ Id. at art. 1210.4.

${ }^{114}$ Outside the scope of free will are also issues which do not belong to the contract statute, including legal (act) capacity, form of contract, ownership relations, and invalidity of contract.

${ }^{115}$ Russian Civil Code, art. 1210.5.

${ }^{116}$ According to Article 1210.6 of the Civil Code, the rules provided in Article 1210, except for that allowing application of different laws, are also to be applied to non-contractual relations where choice of law is allowed.
} 
performance has decisive significance for the content of the contract, is located.

According to the Civil Code ${ }^{117}$, the party whose performance has decisive significance for the content of the contract is the party who is, in particular:

- the seller in a contract of sale;

- the donor in a contract of gift;

- the lessor in a contract of lease;

- the lender in a contract of gratuitous use of property;

- the contractor in a work contract;

- the carrier in a contract of carriage;

- the freight forwarder in a contract for freight forwarding;

- the lender (creditor) in a contract of loan (credit contract);

- the finance agent in a contract of financing against assignment of a monetary claim;

- the bank in a contract of bank deposit and a contract of bank account;

- the bailee in a contract of storage;

- the insurer in a contract of insurance;

- the delegate in a contract of delegation;

- the commission agent in a contract of commission agency;

- the agent in an agency contract;

- the performer in a contract for compensated service;

- the mortgagor in a contract of mortgage, or

- the surety in a contract of suretyship.

Taking into account the specific nature of certain contract types, the provisions of the Civil Code on the law applicable to a contract in the absence of the choice of law clause indicate the applicable law directly. It is so in the case of:

- construction work contracts and contracts for the performance of design and exploratory work - the law of the country in which the results stipulated by the contract are mainly created ${ }^{118}$;

- contracts of simple partnership - the law of the country where its activities are mainly practiced ${ }^{119}$;

- contracts concluded by auction, tender or at exchange - the law of the country where the auction or tender is held or the exchange is located $^{120}$;

- commercial concessions or franchise contracts - the law of the country on which territory the franchisee is permitted to use the granted exclusive rights, or - if the permission covers several countries - the law

\footnotetext{
${ }^{117}$ Russian Civil Code, art. 1211.2.

${ }^{118}$ Id. at art. 1211.3.

${ }^{119} \mathrm{Id}$. at art. 1211.4 .

${ }^{120} \mathrm{Id}$. at art. 1211.5
} 
of the country where the place of residence or main place of activities of the rightholder is located ${ }^{121}$;

- contracts for the alienation of an exclusive right - the law of the country on which territory the granted exclusive right is in effect or, if this covers several countries, the law of the country where the place of residence or main place of activities of the rightholder is located ${ }^{122}$, and

- licence contracts - the law of the country on which territory the licensee is permitted to use the intellectual property object or, if the permission covers several countries, the law of the country in which the place of residence or main place of activities of the licensor is located. ${ }^{123}$

However, the general conflict of laws rules of Article 1211 of the Civil Code are only rebuttable presumptions. According to the subsidiary rule applicable to contract obligations provided by Article 1211.9, the law of the country with which the contract has the closest connection is to be applied if it follows from the law, the terms or the nature of the contract, or the entirety of the circumstances of the case.

The principle of closest connection or the proper law principle is also applicable to a mixed contract. According to Article 1211.10, a contract which contains elements of different types of contracts is to be governed, unless otherwise follows from the law, the terms or the nature of the contract, or the totality of the circumstances of the case, by the law of the country with which this contract as a whole has the closest connection.

b) Law applicable to immovable property contract

According to the Civil Code ${ }^{124}$, the law applicable to a contract in respect of immovable property may be determined by the choice of law clause. In its default, the applicable law is the law of the country with which the contract has the closest connection. The closest connection is regarded, unless otherwise follows from the law, the terms or the nature of the contract, or the totality of the circumstances of the case, to be the country where the property is located. However, in the event that a contract is related to a land plot, mineral resources field or other immovable property, it is to be governed by Russian law.

c) Law applicable to foundation and participation agreements

The provisions of the Civil Code on the law applicable to agreements on the establishment of the juristic person and agreements concerning the exercise of participation rights in a juristic person ${ }^{125}$ allow the choice of law by the parties. They may not, however, exclude the application of the imperative

${ }^{121}$ Id. at art. 1211.6.

${ }^{122} \mathrm{Id}$. at art. 1211.7 .

${ }^{123}$ Id. at art. 1211.8 .

${ }^{124} I d$. at art. 1213.

${ }^{125} I d$. at art. 1214. 
norms of the country in which the juristic person has been founded, which are related to the issues belonging to the personal statute as determined in Article 1202.2 of the Civil Code, as presented above. In the absence of the choice of law clause, the law applicable to agreements on establishment of the juristic person and agreements concerning the exercise of participation rights in a juristic person is the law of the country where it has been or is intended to be established $^{126}$.

\section{Law Applicable to Obligations arising from Fraudulent Contract Negotiations}

According to the Civil Code ${ }^{127}$, obligations arising from fraudulent contract negotiations (culpa in contrahendo) are to be governed by the law applicable to the contract, and, in the event that the contract has been left unconcluded, the law that would have been applied, if the contract had been concluded, is to be applied. But if the law applicable to the case of fraudulent contract negotiations cannot be determined, then the general provisions of the law applicable to obligations arising from causing harm or tort liability are to be applied ${ }^{128} .{ }^{129}$ Also, the rules allowing the choice of law by the parties are applicable in such a case, without prejudice to the rights of third persons and application of imperative norms ${ }^{130}$.

\section{Conclusion}

The reform of the Civil Code concerning international private law legislation has succeeded in integrating judicial practice and international standards, including the necessary flexibility, into Russian law. Due to the adequacy of the novelties, the consistency and coherence of the part of the Civil Code containing international private law rules have been secured. It remains the most sophisticated part of Russian civil law legislation.

\section{References}

Abova, T.E, Boguslavsky, M.M, Kabalkin, A.Y. \& A.G. Lisicin-Svetlanov (eds.) (2007). Постатейный комментарий к Гражданскому кодексу Российской Федерации, Частям I, II и III [Article-specific Commentary to the Civil Code of the Russian Federation, Parts I, II and III]. Moscow.

Abova, T.E., Boguslavsky, M.M. \& A.G. Svetlanov (eds.) (2010). Комментарий к Гражданскому кодексу Российской Федерации Том 2 [Commentary to the Civil Code of the Russian Federation, Volume 2]. Moscow.

Asoskov, A.V. (2015). Реформа раздела VI "Международное частное право" Гражданского кодекса РФ [Reform of Division VI "International Private Law"

\footnotetext{
${ }^{126} I d$. at art. 1214.2.

${ }^{127} \mathrm{Id}$. at art. $1222^{1}$.

${ }^{128}$ The applicable law is mainly the law of the place of the tort (lex loci delicti).

${ }^{129}$ Russian Civil Code, arts 1219-20.

${ }^{130} I d$. at art. $1223^{1}$.
} 
of Civil Code of RF] http://отрасли-права.pф/article/6060_(last accessed Feb. 11, 2016).

Dmitrieva, G.K. (ed.) (2010) Международное частное право [International Private Law]. Moscow.

Doronina, N.G. (2010). Актуальные проблемы международного частного права [Actual Problems of International Private Law]. Журнал российского права [Journal of Russian Law]. 1, pp. 114-126.

Neshatayeva, T.N. (2004). Международное частное право и Международный гражданский процесс [International Private Law and International Civil Procedure]. Moscow.

Stepanov S.A. (ed) (2016). Комментарий к Гражданскому кодексу Российской Федерации [Commentary to the Civil Code of the Russian Federation]. Moscow.

Yarkov V.V. (2007). Access to Justice: Foreign Persons and Russia's New Arbitration Procedure Code (part 1). Review of Central and East European Law. 32. PP. $121-89$. 
